\title{
FUNCTIONING OF NO-CYCLE IN THE SALIVA OF CHILDREN WITH TYPE 1 DIABETES MELLITUS*
}

\author{
I. O. Kuz, O. Ye. Akimov, V. O. Kostenko, \\ O. V. Sheshukova, A. I. Maksymenko, O. A. Pysarenko \\ Poltava State Medical University, Poltava, Ukraine \\ kuz.irina.irinovna@gmail.com
}

Introduction. Type 1 diabetes mellitus $(\mathrm{DM})$ is an autoimmune disease in genetically predisposed individuals. It leads to the destruction of pancreatic B-cells and the development of absolute insulin deficiency. According to the International Diabetes Federation, 642 million people will suffer from diabetes by 2040 . The presence of type 1 diabetes mellitus in children is a major risk factor for periodontal disease. Due to hyperglycemia, metabolism in periodontal tissues may be disrupted, which in turn may leads to the progression of inflammatory processes [8]. Pathogenetically important features of endocrinological diseases such as DM are angiopathy, namely in the vessels of the microcirculatory tract; autoaggression and the occurrence of secondary immunodeficiency; changes in lipid peroxidation; metabolic disorders, which may disrupt function of periodontal tissues $[4,6,14]$.
Chronic hyperglycemia contributes to the development of oxidative stress, vascular inflammation, hyperproduction of nitric oxide (NO) released by inducible NO synthase (iNOS), activation of lipid peroxidation. These mechanisms are important links in the pathogenesis of diabetes complications. Nitric oxide plays a regulatory role in all phases of the inflammatory process. Nitric oxide regulates inflammation, immunomodulation and oxidation in the inflammatory stage. It affects the processes of fibroblast differentiation, collagen synthesis, increases vascularization of tissues, which, in turn, accelerates the final stage of epithelialization. Many authors believe that cells produce NO in the area of inflammation, and all these processes are NO-dependent [2, 12].

Nitric oxide is a biological mediator in the human body. It is a highly reactive molecule and it has oxidizing properties, both directly

* The work was carried out in the framework of research work with the Department of Pediatrics № 2 «Study of pathogenetic mechanisms of the most common diseases of childhood, optimization of their diagnosis and treatment» 2017-2021, state registration № 0117U004683.

Institution, which financed the research: the Ministry of Health of Ukraine.

The authors assume responsibility for the published work.

The authors guarantee absence of competing interests and their own financial interest when carrying out the research and writing the article.

The manuscript was received by the editorial staff 02.07.2021. 
and in the form of more toxic peroxynitrite. These properties determine the bactericidal and cytotoxic effects of $\mathrm{NO}$ and its protective qualities, which are manifested in the stimulation of antimicrobial activity and cytotoxicity $[3,5]$. NO gets into biological fluids due to its and L-citrulline formation from L-arginine and $\mathrm{O}_{2}$ using $\mathrm{NADPH}_{2}$ under the influence of various isoenzymes of nitric oxide synthase (NO-synthase): two constitutive types, namely endothelial NO-synthase (eNOS) and neuronal NO-synthase (nNOS), and inducible NOsynthase (iNOS). Its induction is carried out by proinflammatory cytokines. Neuronal and endothelial nitric oxide synthases are $\mathrm{Ca}^{2+}$-dependent enzymes. The first one is mainly expressed in the central and peripheral nervous system. Endothelial NO-synthase is present mainly in vascular endothelial cells. These two isoforms are constitutive, but in different pathological conditions, their expression can be changed, which is accompanied by a decreasing of NO formation. Physiological production of nitric oxide under the action of constitutive $\mathrm{NO}$-synthase is aimed to maintaining a certain tissue balance in NO metabolism. Macrophage nitric oxide synthase is predominantly iNOS and is not expressed continuously in tissues, but is expressed and synthesized de novo under the influence of inflammatory stimuli. It is $\mathrm{Ca}^{2+}$-independent in its activation and serves as a source of large amounts of NO, which has a detrimental effect on bacteria and viruses. $\mathrm{NO}$ as product of inducible NO-synthase, can enhance the inflammatory changes in the tissues leading to venous congestion [10, 11, 15].

It is known that iNOS expression is activated by a number of factors capable of inducing insulin resistance, such as glucose under conditions of hyperglycemia and free fatty acids. This activation is mediated mainly through the activation of nuclear factor $\mathrm{kB}$ (NF-kB). Violation of NF-kB signaling is considered to be the molecular basis of many pathological processes such as metabolic syndrome and DM $[2,6]$.

Despite the large number of experimental studies, the effect of type 1 diabetes as systemic change in metabolism on the production of NO in the oral cavity is still unclear.

The aim of our research work was to determine the activity of NO-synthase and arginase in oral fluid in children of primary school age with insulin-dependent diabetes mellitus.

\section{MATERIALS AND METHODS}

We examined 82 children (from six to twelve years old), including 56 children with type 1 diabetes mellitus and 26 children without somatic diseases.

According to our dental examination, all the patients were divided into the following subgroups:

Group $1-13$ children with clinically healthy periodontium and no comorbidities, this group was a control one;

Group 2-13 children of children without comorbidities and with chronic catarrhal gingivitis (HCG);

Group $3-26$ children with type 1 diabetes mellitus without signs of periodontitis;

Group $4-30$ children with type 1 diabetes mellitus who had chronic catarrhal gingivitis.

Exclusion criteria: children who had previous orthodontic treatment or were undergoing orthodontic treatment at the time of the examination, current smoking, periodontal treatment or antibiotic therapy in the last 6 months, any other systemic diseases, the presence of eruptive gingivitis at the time examination. We also excluded children with diabetes mellitus with any other complications than periodontal inflammation and children with decompensated diabetes mellitus.

NO-synthase (NOS) activity was determined by the difference in nitrite concentration before and after incubation of tissue homogenate. The activity of nitrites was determined by determining the diazo compounds formed in the reaction with sulfanilic acid, and then carried out the reaction with a-naphthylamine (GrissIlosvay Reagent). As a result, red derivatives (azo dyes) were formed. The intensity of the color is proportional to the activity of nitrites. Aminoguanidine is a selective inhibitor of the inducible form of NOS, so the addition of aminoguanidine to the incubation mixture will determine the activity of NOS constitutive forms.

The method of determining arginase activity was based on analysis the difference in 
the concentration of L-ornithine before and after incubation in phosphate buffer solution containing L-arginine. The concentration of L-ornithine is determined by the color product formed in the reaction with Chinard reagent in Khramov's modification.

We carried out the collection of unstimulated oral fluid in the morning, at the same time, on an empty stomach. Patients were previously asked to rinse the mouth. Sampling was performed by spitting $4 \mathrm{ml}$ of oral fluid into sterile, tightly closed plastic tubes after 30 minutes. The collected oral fluid was delivered to the laboratory.

Statistical processing of the results was performed with the help of Real Statistics ex- tension for Microsoft Excel. The significance of the differences between groups was estimated by Khruskal-Wallis ANOVA test with following paired comparison by Mann-Whitney test. Differences were deemed significant if $p$ was lower than 0.05 .

The scientific materials comply with the rules of humane treatment of patients in accordance with the requirements of the Tokyo Declaration of the World Medical Association, international recommendations of the Helsinki Declaration of Human Rights, the Council of Europe Convention on Human Rights and Biomedicine, Laws of Ukraine, the orders of the Ministry of Health of Ukraine and ethics code of requirements of Ukraine.

\section{RESULTS AND THEIR DISCUSSION}

We did not find a statistically significant difference between groups 1 and 2 . There were no significant changes in the composition of saliva in somatically healthy children with healthy gums and somatically healthy children with chronic catarrhal gingivitis. The values of inducible NO synthase and arginase are almost indistinguishable in these groups (Table).

A statistically significant difference was found for all isoforms of NO-synthase and arginase between groups 1 and 3 . We had noted an increase in the value of iNOS in 1.65 times and a decrease in ARG in 1.57 times, when we compared the values of inducible NO-synthase and arginase between groups 1 and 3 (in somatically healthy children with healthy gums and children with type 1 diabetes mellitus with healthy gums). An increase in the iNOS/ARG index demonstrates the predominance in the oral fluid of the L-arginine breakdown by the NOS-dependent pathway, which could lead to excessive NO production and the development of nitrosative stress. Such a violation of the indicators' balance showed us a decrease in regenerative capacity in the mucous membrane in persons with type 1 diabetes mellitus.

A statistically significant difference was observed in the activity of constitutional, inducible synthase, $\mathrm{NO}_{2}$ content and arginase activity between children with type 1 diabetes mellitus with healthy gums (group 3) and chronic catarrhal gingivitis (group 4). The activity of iNOS in group 4 decreased by 1.23 times compared with group $3, \mathrm{NO}_{2}$ decreased by 1.44 times, and the activity of ARG increased in 1.71 times. Increased ARG activity in group 4 children may lead to competition between NOS and ARG for L-arginine, resulting in the separation of cNOS from the substrate and the transition of cNOS to superoxide anion radical production instead of productive NO [7, 9].

We also compared the level of glycosylated hemoglobin in groups 3 and 4. Glycosylated hemoglobin (A1c (HbA1c)) shows the average blood glucose level in recent months. The norm is $4-5.6 \%$. The level of A1c (HbA1c) in the groups of children with type I diabetes is almost twice as high as normal and is $9.47 \%$ \pm 0.50 in group 3 and $8.11 \pm 0.22 \%$ in group 4 . We found a statistically significant difference in the level of A1c (HbA1c) in the groups of children with diabetes mellitus. That is why we should take into account not only the presence of local factor (chronic catarrhal gingivitis), but also the important role of hyperglycemia in the development of nitrosative stress, when we compare the activity of constitutional, inducible synthase, $\mathrm{NO}_{2}$ and arginase level in groups 3 and 4.

A statistically significant difference was also observed for all isoforms of NO-synthases and $\mathrm{NO}_{2}$ between groups 1 and 4 (control group and group of children with chronic catarrhal gingivitis). The activity of inducible NO-synthase in group 4 is 1.35 times bigger than in group 1. ARG activity in group 4 is 


\section{NO-synthase and arginase activity in the oral fluid of somatically healthy children and children with type 1 diabetes mellitus}

\begin{tabular}{|c|c|c|c|c|}
\hline \multirow{3}{*}{ Indexes } & \multicolumn{4}{|c|}{ Groups } \\
\hline & $\begin{array}{c}\text { Healthy } \\
\text { children } \\
n=13\end{array}$ & $\begin{array}{c}\text { Healthy } \\
\text { children with } \\
\text { HCG } \\
\text { n }=13\end{array}$ & $\begin{array}{l}\text { Children with } \\
\text { type I diabetes } \\
\text { and healthy } \\
\text { gums } \\
n=26\end{array}$ & $\begin{array}{l}\text { Children with } \\
\text { type I diabetes } \\
\text { and HCG } \\
n=30\end{array}$ \\
\hline & 1 & 2 & 3 & 4 \\
\hline $\begin{array}{l}\text { gNOS, } \mu \mathrm{mol} / \mathrm{min} \text { per } \mathrm{g} \\
\text { of protein }\end{array}$ & $\begin{array}{c}0,54 \pm 0,02 \\
* * \\
* * * * *\end{array}$ & $\begin{array}{c}0,55 \pm 0,02 \\
* * * *\end{array}$ & $0,87 \pm 0,07$ & $0,75 \pm 0,04$ \\
\hline $\begin{array}{l}\mathrm{cNOS}, \mu \mathrm{mol} / \mathrm{min} \text { per } \mathrm{g} \\
\text { of protein }\end{array}$ & $\begin{array}{c}0,09 \pm 0,001 \\
* * \\
* * * * *\end{array}$ & $\begin{array}{c}0,09 \pm 0,001 \\
* * * *\end{array}$ & $\underset{* * *}{0,11}+0,001$ & $0,13 \pm 0,004$ \\
\hline $\begin{array}{l}\text { iNOS, } \mu \mathrm{mol} / \mathrm{min} \text { per } \mathrm{g} \\
\text { of protein }\end{array}$ & $\begin{array}{c}0,46 \pm 0,02 \\
* * \\
* * * * *\end{array}$ & $\begin{array}{c}0,46 \pm 0,02 \\
* * * *\end{array}$ & $\begin{array}{c}0,76 \pm 0,07 \\
* * *\end{array}$ & $0,62 \pm 0,04$ \\
\hline $\mathrm{NO}_{2}, \mathrm{nmol} / \mathrm{L}$ & $\begin{array}{c}2,53 \pm 0,11 \\
* * \\
* * * * *\end{array}$ & $\begin{array}{c}2,50 \pm 0,20 \\
* * * *\end{array}$ & $\begin{array}{c}1,93 \pm 0,15 \\
* * *\end{array}$ & $1,34 \pm 0,14$ \\
\hline $\begin{array}{l}\mathrm{ARG}, \mu \mathrm{mol} / \mathrm{min} \text { per } \mathrm{g} \\
\text { of protein }\end{array}$ & $\begin{array}{c}0,66 \pm 0,02 \\
* *\end{array}$ & $0,67 \pm 0,02$ & $\begin{array}{c}0,42 \pm 0,03 \\
* * *\end{array}$ & $0,72 \pm 0,03$ \\
\hline iNOS/ARG ratio & 0,70 & 0,69 & 1,81 & 0,86 \\
\hline
\end{tabular}

Note:

* the difference is significant between groups 1 and $2, \mathrm{p}<0,05$;

$* * \quad$ the difference is significant between groups 1 and $3, \mathrm{p}<0,05$;

$* * * \quad$ the difference is significant between groups 3 and $4, p<0,05$;

$* * * * \quad$ the difference is significant between groups 2 and $4, p<0,05$;

$* * * * *$ the difference is significant between groups 1 and $4, p<0,05$.

$0.72 \pm 0.03$, so there was no statistically significant difference with a similar indicator in the first group, but the value of this indicator was almost twice as high as in children of group 3. It can be assumed that changes in the activities of NOS isoforms are a consequence of the systemic effects of insulin deficiency because these changes are similar to the changes observed in group 3 when comparing with group 1 $[1,13]$.

It should be noted that there was no statistically significant difference in the values of ARG activity in groups 2 and 4 (healthy children with HCG and children with type I diabetes and HCG). It was high enough compared with groups of children with healthy gums and evidenced about the activation of regenerative processes. The lack of changes in ARG activity can be explained by dysregulation in the nitric oxide cycle caused by a local factor (gingivitis). Increased ARG activity in groups 2 and 4 compared with group 1 indicated an adaptive response aimed at repairing gum damage, as the result of arginase cleavage of L-arginine is the formation of powerful regeneration stimulants - polyamines (spermine, spermidine). The activity of iNOS in group 4 was 1.35 times greater than in group 2. Based on this, increased NO production from NOS is a consequence of insulin deficiency (systemic factor) $[2,4,12,14]$.

It is known that both constitutive and inducible NO-synthases play a role in the production of $\mathrm{NO}$ in the early phase of inflammation, thereby demonstrating its pro-inflammatory effect. At the same time, NO-synthases control the biosynthesis of proinflammatory interleukins, which are inhibitors of the inflammatory 
response. Thus, NO synthases and nitric oxide produced by them are "true» regulators of inflammation.

The content of nitrates and nitrites in the oral fluid is a rather variable feature. We should take into account not only the number of stable metabolites of NO, but also the activ- ity of nitrate-nitrite reductase complex, when quantifying the content of $\mathrm{NO}$ in the oral cavity. The accumulation of nitrites and nitrates in the oral fluid with low activity of reductase enzymes is an unfavorable prognostic sign and indicates inflammatory processes in the gums.

\section{CONCLUSIONS}

Activity of inducible NO-synthase has a significant impact on the formation of stable NOmetabolites in the oral cavity of primary school children with type 1 diabetes mellitus.

The presence of chronic catarrhal gingivitis both in healthy children and in children with type 1 diabetes mellitus does not change the formation of stable NO metabolites in the oral cavity, though its presence triggers the adaptive reaction by increasing the arginase activity.

The combination of systemic factor (type 1 diabetes mellitus) and local (chronic catarrhal gingivitis) leads to dysregulation of the NOcycle and increasing of competition between NOS and ARG.

\section{REFERENCES}

1. Akimov OY, Kostenko VO. Ukr Biochem J 2016;88(6): 70-75. https://doi.org/10.15407/ubj88.06.070.

2. Amirshahrokhi K, Zohouri A. Cytokine 2021;138: 155394. https://doi.org/10.1016/j.cyto.2020.155394.

3. Barbadoro P, Ponzio E, Coccia E, et al. Nitric Oxide 2021; 106: 66-71. https://doi.org/10.1016/j.niox.2020.11.002.

4. Davanso MR, Crisma AR, Braga TT, et al. Clin Sci (Lond) 2020; 2: 13-48. https://doi.org/10.1042/CS20201348.

5. De Farias JO, de Freitas Lima SM, Rezende TMB. Clin Oral Investig 2020;24(12): 4197-4212. https://doi. org/10.1007/s00784-020-03629-2.

6. Gazyakan E, Hirche C, Reichenberger MA, et al. Ann Plast Surg 2020;84(1): 106-112. https://doi.org/10.1097/ SAP.0000000000002121.

7. Guerby P, Tasta O, Swiader A, et al. Redox Biol 2021;40: 101-861. https://doi.org/10.1016/j.redox.2021.101861.

8. Maksymenko AI, Sheshukova OV, Kuz IO, et al. Wiadomości Lekarskie 2021;LXXIV(6): 1336-1340. https://doi. org/10.36740/WLek202106109.
9. Molnar T, Horvath A, Szabo Z, et al. Scand Cardiovasc J 2021;55(2): 97-101. https://doi.org/10.1080/14017431.2 020.1821911.

10. Pignatelli P, Fabietti G, Ricci A, et al. Int J Mol Sci 2020; 21(20): 75-88. https://doi.org/10.3390/ijms21207538.

11. Rosier BT, Moya-Gonzalvez EM, Corell-Escuin P, Mira A. Front Microbiol 2020;11: 54-65. https://doi.org/ 10.3389/fmicb.2020. 555465 .

12. Somayajulu M, McClellan SA, Pitchaikannu A, et al. J Ocul Pharmacol Ther 2021;37(1): 12-23. https://doi. org/10.1089/jop.2020.0105.

13. Soodaeva S, Klimanov I, Kubysheva N, et al. Oxid Med Cell Longev 2020; 19: 85-92. https://doi.org/10.1155/ $2020 / 4859260$.

14. Ünüvar S, Melekoğlu R, Şalva E, et al. J Diabetes Metab Disord 2020;19(2): 1391-1396. https://doi.org/10.1007/ s40200-020-00659-1.

15. Zahorán S, Szántó PR, Bódi N, et al. Antioxidants (Basel) 2021;10(4): 575-583. https://doi.org/10.3390/antiox10040583. 


\title{
FUNCTIONING OF NO-CYCLE IN THE SALIVA OF CHILDREN WITH TYPE 1 DIABETES MELLITUS
}

\author{
I. O. Kuz, O. Ye. Akimov, V. O. Kostenko, O. V. Sheshukova, A. I. Maksymenko, O. A. Pysarenko \\ Poltava State Medical University, Poltava, Ukraine \\ kuz.irina.irinovna@gmail.com
}

Introduction. The presence of type 1 diabetes mellitus in children is a major risk factor for periodontal disease.

The aim of research work was to determine the activity of NO-synthase and arginase in saliva in children age with insulin-dependent diabetes mellitus.

Materials and methods. We examined 82 children including 56 children with type 1 diabetes mellitus and 26 children without somatic diseases.

NO-synthase (NOS) activity was determined by the difference in nitrite concentration before and after incubation of tissue homogenate. Determining arginase activity was based on analysis the difference in the concentration of L-ornithine before and after incubation in phosphate buffer solution. Statistical processing of the results was performed with the help of Real Statistics extension for Microsoft Excel. The significance of the differences between groups was estimated by Khruskal-Wallis ANOVA test with following paired comparison by Mann-Whitney test.

Research results and their discussion. The violation of the indicators' balance between groups of healthy children with healthy gums and children with diabetes mellitus and healthy gums showed us a decrease in regenerative capacity in the mucous membrane in persons with type 1 diabetes mellitus. Increased ARG activity in group of children with type 1 diabetes mellitus and chronic catarrhal gingivitis may lead to rivalry between NOS and ARG for L-arginine. Increased ARG activity in group of somatically healthy children with chronic catarrhal gingivitis and children with type 1 diabetes mellitus and chronic catarrhal gingivitis compared with group of healthy children with healthy gums indicated an adaptive response aimed at repairing gum damage. Based on this, increased NO production from NOS is a consequence of insulin deficiency (systemic factor).

Conclusions. The combination of systemic factor (type 1 diabetes mellitus) and local (chronic catarrhal gingivitis) leads to dysregulation of the NO-cycle and increasing of competition between NOS and ARG.

Key words: type 1 diabetes mellitus, children, NO-synthase, arginase, gingivitis.

\section{ФУНКЦІОНУВАННЯ NO-ЦИКЛУ В СЛИНІ ДІТЕЙ З ЦУКРОВИМ ДІАБЕТОМ І ТИПУ}

\author{
Кузь І. О., Акімов О. Є., Костенко В. О., Шешукова О. В., Максименко А. І., Писаренко О. А. \\ Полтавський державний медичний університет, м. Полтава, Украйна \\ kuz.irina.irinovna@gmail.com
}

Вступ. Наявність цукрового діабету І типу у дітей е основним фактором ризику розвитку захворювань пародонту.

Метою дослідницької роботи було визначити активність NO-синтази та аргінази у слині у дітей віку з інсулінозалежним цукровим діабетом.

Матеріали і методи. Ми обстежили 82 дитини, у тому числі 56 дітей із цукровим діабетом I типу та 26 дітей без соматичних захворювань. Активність NO-синтази (NOS) визначали за різницею в концентрації нітритів до та після інкубації гомогенату тканини. Визначення активності аргінази базувалося на аналізі різниці концентрацій L-орнітину до та після інкубації в розчині фросфатного буфера. Для визначення статистичної значущості відмінностей між групами ми застосували дисперсійний аналіз ANOVA за методом Хрускала-Уоліса із послідуючим попарним порівнянням за методом МаннаУітні із внесенням поправки за Бонфероні.

Результати досліджень та їх обговорення. Порушення балансу показників між групами дітей із клінічно здоровим пародонтом та відсутніми супутніми захворюваннями і групою дітей, хворих на цукровий діабет I типу без ознак запалення пародонту показало нам зниження регенеративної здатності слизової оболонки у хворих на цукровий діабет I типу. Підвищена активність ARG у групи дітей, хворих на цукровий діабет I типу, в яких було діагностовано хронічний катаральний гінгівіт, може призвести до різного співвідношення NOS та ARG щодо L-аргініну. Підвищена активність ARG у групах дітей дітей без супутніх захворювань, але, яким було діагностовано хронічний катаральний гінгівіт, та групі дітей, хворих на цукровий діабет I типу, в яких було діагностовано хронічний катаральний гінгівіт, порівняно з контрольною групою дітей із клінічно здоровим пародонтом та відсутніми супутніми захворюваннями свідчила про адаптивну реакцію, спрямовану на відновлення пошкодження ясен. Виходячи з цього, збільшення продукції NO із NOS е наслідком дефіциту інсуліну (системний фрактор).

Висновки. Поєднання системного фактору (цукровий діабет I типу) та місцевого (хронічний катаральний гінгівіт) призводить до порушення регуляції NO-циклу та посилення конкуренції між NOS та ARG.

К лючові слов а: цукровий діабет I типу, діти, NO-синтаза, аргіназа, гінгівіт. 